\title{
The Effect of Increasing Teacher Competency and Vice Principal Leadership of Academic Schools on Teacher Success at SMP Negeri 1 Mesuji
}

\author{
${ }^{1}$ SMPN 1 Mesuji, South of Sumatra, Indonesia \\ ${ }^{2}$ Universitas PGRI Palembang, Indonesia \\ *Corresponding author. Email: yosiariska22@gmail.com
}

Yosi Ariska ${ }^{1 *}$, Bukman Lian $^{2}$, Mulyadi $^{2}$

\begin{abstract}
The purpose of this study is to resolve the problems, first, the impact of increasing teacher competence on the performance of teachers. Second, the effect of the Deputy Principal's Instructional Leadership on Teacher Results. Third, the influence on the teaching output of SMPN 1 Mesuji of increasing the competence and leadership of the vice-principal in the academic sector. Associative research is the nature of this research. The overall population is the same as the SMPN 1 Mesuji study survey, with a total of 30 teachers as respondents. The statistical analysis methodology method used is a multi-linear regression analysis. The results of the F-test research have a major impact on the independent variables, namely Increased Teacher Competence $\left(\mathrm{X}_{1}\right)$ and the Leadership of the Vice Principals $\left(\mathrm{X}_{2}\right)$ on the Bound Variable, namely Teacher Success (Y). SMPN 1 Mesuji. The first $t$ test notes that there is a major impact of increasing teacher competence $\left(\mathrm{X}_{1}\right)$ on the output of teachers $(\mathrm{Y})$. Second, there is a major impact of VicePrincipal Leadership $\left(\mathrm{X}_{2}\right)$ on the success of teachers $(\mathrm{Y})$.
\end{abstract}

Keywords: Competency, Leadership, Teacher Performance

\section{INTRODUCTION}

The standard of education cannot be distinguished from that of the teacher, which is a feature of the implementation of education. The standard of education affects the status and the strategic role of teachers. According to Mustafa [1] if the teacher's competence is poor, students will become a low-quality generation. As a consequence, the standard of education and graduates is often seen as relying on the role of the teacher in handling the learning components used in the teaching and learning process, which is the responsibility of the school.

Teacher success is a learning method to achieve the educational aims of all teaching efforts. The success of the teacher involves a set of activities related to their professional competence as a teacher and the competence of the teacher for personal development. The performance of teachers at school plays an important role in the achievement of school objectives and the standard of learning. One metric for the implementation of learning can be used as a reflection and measurement of the level of learning that must be accomplished through the performance of teachers. The current status of teachers still indicates, in different ways, that their success is not optimum. Not ideal because the working environment of the company at work has not been optimal and cannot be isolated from the influence of the vice-principal in academia.

The above explanation is the reason why the researcher wishes to prove that there is "The Effect of Increased Competence of Teachers and the Leadership of Vice Principals for Academic Affairs on Teacher Performance at SMP 1 Mesuji" which is the title of this study. The purpose of this study is to resolve the problems, first, the impact of increasing teacher competence on the performance of teachers. Second, the effect of the Deputy Principal's Instructional Leadership on Teacher Results. Third, the influence of increasing the competence and leadership of the vice-principal in the academic sector on the success of teachers at SMPN 1 Mesuji.

Teacher competence is a mixture of personal, science and technical, social and spiritual skills, which are the core competencies of the teaching profession, including mastery of resources, student comprehension, learning, personal growth and professionalism [1] 
According to BNSP number 16 of 2007 concerning Academic Qualification Standards and Teacher Competencies, there are four Teacher Competencies, namely: 1) pedagogic competence; 2) personality competencies; 3) social competence, and 4) professional competence.

Leadership is one of the managerial aspects of organizational life which is a key position. Because the leadership of a leader acts as a harmonizer in the process of cooperation between people in their organization [2]. Dynamic and effective leadership is the most basic potential and which is difficult to find, but that does not mean that a leader is not capable of being a leader who has dynamic and effective leadership. Understanding leadership theory will be able to increase his understanding of himself, find out the weaknesses and strengths of his potential, and will be able to increase understanding of how should treat his subordinates.

Leadership in organizations has a very large role in building relationships between individuals and forming organizational values which serve as the basic foundation for achieving organizational goals. The influence of leadership on organizational effectiveness can be seen as a direct and indirect leadership effect.

In the operational training unit of the organizational management, one of which is in the field of curricula, this field is responsible for the implementation of the process, especially in the academic field, in the promotion of students. The management definition is, of course, tailored to the general policy line that applies to management. This management was decided upon at the work meeting of the school unit. The management policy line offers a strategic guideline for the creation of organizational directions for academic management in terms of vision, purpose, quality policy, the competence of school members with regard to teachers and students [3].

\section{METHODS}

Methodology is a determining factor for the merits of writing scientific papers [4]. This study uses an associative research design. According to Sugiyono [5] "Associative research is research that aims to determine the relationship between two or more variables. This research will build a theory that can serve to explain, predict, and control a symptom. "The variables in this study used independent variables, namely teacher competence $\left(\mathrm{X}_{1}\right)$ and vice principal leadership $\left(\mathrm{X}_{2}\right)$ with the dependent variable being teacher success $(\mathrm{Y})$. The conceptual framework of this study was to determine the effect of teacher competence and vice principal leadership on teacher performance. at SMP Negeri 1 Mesuji, Mesuji Induk District, OKI Regency.

The population in this analysis is either a sample or samples are taken from both populations. According to Sugiyono [4] the method used to assess a sample when all representatives of the population are used as a sample is called a saturated sample. This saturated survey shall be taken if the population is less than or equal to 30 respondents. Research results can be collected from the research sample in connection with this research, which is carried out using quantitative methods. The sample is part of the overall analysis [6].

The sampling technique is carried out by referring to the opinion of Sugiyono [7] which states that sampling can be carried out in a variety of ways, including by using the Probability sampling technique. This sampling technique has been carried out in conjunction with the research needs. As a result, the researcher reported that the samples in this study were teachers and employees of SMP Negeri 1 Mesuji in the second half of the $2020 / 2021$ school year, with a total of 30 people. Based on the suggested problems and assumptions, the statistical analysis methodology method used is a multiple linear regression analysis.

\section{RESULTS AND DISCUSSION}

Table 1. Multiple Regression Coefficient Results

\begin{tabular}{|c|c|c|c|c|c|c|}
\hline \multicolumn{7}{|c|}{ Coefficients $^{\mathrm{a}}$} \\
\hline \multirow{2}{*}{\multicolumn{2}{|c|}{ Model }} & \multicolumn{2}{|c|}{ Unstandardized Coefficients } & \multicolumn{3}{|c|}{ Standardized Coefficients } \\
\hline & & $\mathrm{B}$ & Std. Error & Beta & $\mathrm{t}$ & Sig. \\
\hline \multirow[t]{3}{*}{1} & (Constant) & -.121 & 1.095 & & -.111 & .913 \\
\hline & Competence $\left(\mathrm{X}_{1}\right)$, & .397 & .171 & .416 & 2.319 & .028 \\
\hline & Leadership $\left(\mathrm{X}_{2}\right)$ & .507 & .237 & .384 & 2.137 & .042 \\
\hline
\end{tabular}

Based on Table 1. the following multiple regression equation is obtained:

$$
Y=-0,121+0,397 X_{1}+0,507 X_{2}
$$


Table 2. Correlation Test Results

\begin{tabular}{|c|c|c|c|c|}
\hline \multicolumn{5}{|c|}{ Model Summary ${ }^{b}$} \\
\hline Model & $\mathrm{R}$ & R Square & Adjusted R Square & Std. Error of the Estimate \\
\hline 1 & $.467^{\mathrm{a}}$ & .219 & .161 & .620065 \\
\hline \multicolumn{5}{|c|}{ a. Predictors: (Constant), Competence $\left(\mathrm{X}_{1}\right)$, Leadership $\left(\mathrm{X}_{2}\right)$} \\
\hline
\end{tabular}

Based on the results of the calculation, the coefficient of correlation (R) was found to be 0.467 . From the results obtained by linking the results of the correlation coefficient to the level of proximity between the variables of 0.467 , which is in the interpretation of the correlation value (0.40-0.599), the relationship between the two variables is important and the level of proximity is mild.

The results of the measurements using the SPSS For Windows software indicate that the value of $\mathrm{R}^{2}=0.219$, which means that the Teacher Competence Improvement Variable $\left(\mathrm{X}_{1}\right)$, the Leadership of the Deputy Principal $\left(\mathrm{X}_{2}\right)$ is able to explain the Teacher Output Variable by 0.219 or $21.9 \%$, while the remaining variable is $78,1 \%$ explained by other variables not studied. Based on Table 3. the coefficient of determination is assumed to be mild $(\mathrm{R}=0.467)$. For this purpose, the researcher suggests that other researchers carry out similar research in order to expand this research with other variables beyond the variables currently used by the researcher.

Based on Table 1, it can be shown that the score for the Teacher Competency Development Variable $\left(\mathrm{X}_{1}\right)$ is 2.319, while the Deputy Principal Leadership Variable $\left(\mathrm{X}_{2}\right)$ is 2.137 , compared with the table $\mathrm{t}=2.04541$. The calculation results suggest that the count of the two independent variables on the dependent variable is greater than the $\mathrm{t}$ table (tcount $>$ ttable), so that the parameters for $\mathrm{Ha}$ are accepted and Ho is rejected, which means that the three independent variables may be assumed to have a substantial impact on the dependent variable. On the other hand, when comparing the Sig coefficient. With a P-value of 0.05 , it can be shown that the coefficient is $\mathrm{Sig}$. The value of vector $\mathrm{X}_{1}$ is 0.028 , the coefficient is Sig. The vector $\mathrm{X}_{2}$ is 0.042 , the two independent variables have a Sig coefficient. Which is still below the $\mathrm{P}$-value, this means that $\mathrm{Ha}$ is accepted and $\mathrm{HO}$ is rejected, which means that there is a substantial relationship between the Teacher Competency Improvement Variable $\left(\mathrm{X}_{1}\right)$ and the Leadership of the Deputy Principal $\left(\mathrm{X}_{2}\right)$ on the Bound Variable, namely Teacher Efficiency (Y ).

1. Effect of Improving Teacher Competence and Leadership of Deputy Principals Jointly on Teacher Success at SMPN 1 Mesuji.

Increased teacher competence and the leadership of the Deputy Principals have a direct influence on the success of teachers together. This is the product of the statistical estimation of the $\mathrm{F}$ test as discussed earlier.

The findings of this study are consistent with the theory put forward by Mangkunegara [8] that the measurement of performance success can be assessed through the Development of Teacher Competence and Leadership. How is an instructor doing his tasks, such that it can be used as an example to other students. Wibowo [9] suggests that competence is a stimulus that is an opportunity for a variety of human behavioral processes to accomplish goals. While the elements of competence include the elements of awakening, guiding, sustaining, displaying strength, being continuous and having a mission. Busro [2] also notes that competence is a guiding motivation among individuals to carry out such tasks to achieve objectives. By having the right incentive, teachers would be motivated to do their best to carry out their duties.

2. Impact of Partially Improved Teacher Competence on Teacher Success at SMPN 1 Mesuji.

After the t test was carried out in order to see the effect partially, it was reported that the improvement in the competence of the teacher was important for the performance of the teacher. This is because the teaching of teachers is in line with their function as teaching staff.

The findings of this study are in line with the theory put forward by Mangkunegara [7], which notes that the measure of performance success can be determined by competence. How is the job skill of a teacher carried out in the execution of his duties, such that it can be used as an example for other teachers.

3. Partial effect of the Deputy Principal on Teacher Success at SMPN 1 Mesuji.

After the t-test was carried out in order to see the impact partially, it was reported that the leadership of the Deputy Principal was important for the success of the instructor.

The contribution of the Vice-leadership Principal's is greater than the skill of the teacher. This is because the leadership of the Deputy Principal is a role model for school teachers. In line with Wibowo's theory [8], it is proposed that leadership is an opportunity for a variety of human behavioral processes to accomplish goals. While the elements of motivation include the elements of awakening, guiding, sustaining, displaying strength, being continuous and having an intent. Busro [2] also 
notes that leadership is the guiding force within the person to carry out such tasks to achieve objectives. By having the right incentive, teachers would be inspired to do their best to carry out their duties. They assume that, with the success of the company in achieving its goals and objectives, their personal interests will also be maintained. Modern schooling carries the fate of accountability for destructive developments in the moral and spiritual domain of humanity [10].

\section{CONCLUSION}

Based on the findings of the analysis and discussion, the researchers have drawn a range of conclusions, namely: 1) the results of the study show that the teacher competence variable has a positive and important impact on the output of the SMPNegeri 1 Mesuji teacher; 2) the Vice Principal Leadership Variable also has a strong and important influence on the success of SMP Negeri 1 Mesuji's teaching staff; 3) the relationship between teacher ability development variables and the vice-principal leadership has a positive and important impact on the success of teachers at SMP 1 Mesuji, and 4) the effects of the measurement of the value of $\mathrm{R} 2=0.219$, which implies that the Variable for Improved Teacher Competence $\left(\mathrm{X}_{1}\right)$, the Leadership of the Deputy Principal $\left(\mathrm{X}_{2}\right)$ is capable of explaining the Teacher Output Variable of 0.219 or 21.9 per cent, while the remaining 78.1 per cent is explained by other variables not examined. Based on Table 4.20, the coefficient of determination is assumed to be mild ( $\mathrm{R}=$ 0.467). For these findings, the researcher suggests that other researchers carry out similar research in order to enhance this research using other variables beyond the variables currently used by the researcher.

\section{ACKNOWLEDGMENTS}

The author would like to thank Dr. H. Bukman Lian, M.M., M.Si., Chancellor of the PGRI Palembang University, Dr. Syaiful Eddy, M.Sc., Director of the Postgraduate Program at the PGRI Palembang University, Dr. Happy Fitria, M.Pd., Head of Education Management Study Program and all those who have helped morally and materially. May the goodness become multiple good deed.

\section{REFERENCES}

[1] Musfah, J. (2011). Peningkatan Kompetensi Guru Melalui Pelatihan dan Sumber Belajar Teori dan Sumber belajar Teori dan Praktek [Increasing Teacher Competence through Training and Learning Resources Theory and Learning Resources Theory and Practice]. Jakarta: Kencana.

[2] Busro, M. (2018). Manajemen Sumberdaya Manusia [Human Resource Management] Edisi Revisi. Penerbit Prenada Jakarta.
[3] Eros, E. (2014). Pengaruh motivasi dan kedisiplinan kerja guru terhadap kinerja guru di smp negeri kecamatan brebes kabupaten brebes jawa tengah [The influence of motivation and work discipline of teachers on teacher performance in public junior high schools, Brebes sub-district, Brebes district, Central Java]. Jurnal Administrasi Publik dan Birokrasi, 1(1), 72280.

[4] Muttaqin, K., \& Rahmadoni, J. (2020). Analysis And Design of File Security System AES (Advanced Encryption Standard) Cryptography Based. Journal of Applied Engineering and Technological Science (JAETS), 1(2), 113-123. https://doi.org/10.37385/jaets.v1i2.78

[5] Sugiyono. (2020). Metode Penelitian Kualitatif [Qualitative Research Methods]. Bandung: Alfabeta.

[6] Sukardi. (2011). Metodologi Penelitian Pendidikan [Educational Research Methodology]. Jakarta: Bumi Aksara

[7] Sugiyono. (2017). Metode Penelitian Kombinasi (mixed methods) [Combined research methods (mixed methods)]. Bandung: Alfabeta.

[8] Mangkunegara. (2011). Manajemen Sumberdaya Manusia [Human Resource Management]. Edisi Delapan Penerbit Pustaka Jaya Jakarta.

[9] Wibowo. (2010). Manajemen Kinerja [Performance Management]. Edisi Tujuh. Penerbit PT. Grafindo Rajawali. Jakarta.

[10] Maseleno, A., Ayshwary, B., Ivanova, T. N., Hashim, W., Nguyen, P. T., Shankar, K., Kristiawan, M., Huda, M. (2019). General Theoretical and Philosophical Aspects of Modern Education. Aspectos Teóricos y Filosóficos Generales de la Educación Moderna. Revista San Gregorio 2019, No. 32 Special Issues August. 